\title{
The Development Agenda for Intellectual Property
}

Citation for published version (APA):

Kamperman Sanders, A. W. J. (2005). The Development Agenda for Intellectual Property. Unigraphic. https://doi.org/10.26481/spe.20050520aks

Document status and date:

Published: 20/05/2005

DOI:

10.26481/spe.20050520aks

Document Version:

Publisher's PDF, also known as Version of record

\section{Please check the document version of this publication:}

- A submitted manuscript is the version of the article upon submission and before peer-review. There can be important differences between the submitted version and the official published version of record.

People interested in the research are advised to contact the author for the final version of the publication, or visit the DOI to the publisher's website.

- The final author version and the galley proof are versions of the publication after peer review.

- The final published version features the final layout of the paper including the volume, issue and page numbers.

Link to publication

\footnotetext{
General rights rights.

- You may freely distribute the URL identifying the publication in the public portal. please follow below link for the End User Agreement:

www.umlib.nl/taverne-license

Take down policy

If you believe that this document breaches copyright please contact us at:

repository@maastrichtuniversity.nl

providing details and we will investigate your claim.
}

Copyright and moral rights for the publications made accessible in the public portal are retained by the authors and/or other copyright owners and it is a condition of accessing publications that users recognise and abide by the legal requirements associated with these

- Users may download and print one copy of any publication from the public portal for the purpose of private study or research.

- You may not further distribute the material or use it for any profit-making activity or commercial gain

If the publication is distributed under the terms of Article $25 \mathrm{fa}$ of the Dutch Copyright Act, indicated by the "Taverne" license above, 
The Development Agenda for Intellectual Property

Rational Humane Policy or

"Modern-day Communism" 


\section{Colophon}

Layout and print: Unigraphic, Universiteit Maastricht.

Cover illustration by Zapiro. Used with kind permission of the artist.

Originally published in the Mail and Guardian 15-02-2001 @ Zapiro.

ISBN 90-5681-221-1

NUR 822

Alle rechten voorbehouden. Niets uit deze uitgave mag worden verveelvoudigd, opgeslagen in een geautomatiseerd gegevensbestand of openbaar gemaakt, zonder voorafgaande schriftelijke toestemming van de auteur of uitgever. 


\section{The Development Agenda for Intellectual Property \\ Rational Humane Policy or \\ "Modern-day Communism"?}

Inaugural Lecture

Delivered on the occasion of the acceptance of the chair of European and International Intellectual Property Law. Sponsored by the Institute of European Studies of Macau.

20 May 2005

Dr.mr. Anselm Kamperman Sanders 

Mijnheer de Rector Magnificus,

Dames en Heren, Ladies and Gentlemen,

On this occasion I would like to address you on the Development Agenda for the World Intellectual Property Organisation (WIPO) and the role of intellectual property rights (IPR) in fostering innovation and technology transfer. More in particular, the mounting pressure from developing nations to view intellectual property not just as a means to guarantee the interests of rightholders, but also to bring about economic development and welfare for the whole of global society. A balance of interest between IPR and the public domain features high on the agenda of new international initiatives aiming to harmonize and streamline IPR and procedures. Public interest concerns and a development dimension are key features in the search for this balance. This is why there is mounting pressure to make current discussions on a draft Substantive Patent Law Treaty (SPLT) and also the existing intellectual property framework subject to a so-called "Development Agenda for WIPO". This Development Agenda aims to bridge the gap that separates wealthy nations from the poor.

In the fall of 2004 Argentina and Brazil submitted a formal proposal to the WIPO relating to the establishment of a new development agenda within WIPO.' The proposal addresses the "knowledge gap" and "digital divide" that separates wealthy nations from developing nations and calls for a case-by-case assessment of the role of intellectual property and its impact on development. Whereas in the previous years the prevailing trend has been to harmonise international legal norms through the World Trade Organisation's (WTO) Agreement on Trade Related Aspects of Intellectual Property (TRIPS Agreement), there is now a clear call for increased flexibility.

This flexibility should not only be exercised in respect of the existing obligations and their permitted limitations under the TRIPS Agreement, but should also prompt WIPO to act in consistence with the United Nation's Millennium Development Goals. ${ }^{2}$ In this respect

1. WO/GA/31/11 of August $27,2004$.

2. See www.developmentgoals.org/. The goals are: 1) Eradicate extreme poverty and hunger, 2) Achieve universal primary education, 3) Promote gender equality and empower women, 4) Reduce child moralist, 5) Improve maternal health, 6) Combat HIV/AIDS, malaria, and other diseases, 7) Ensure environmental sustainability, 8) Develop a global partnership for development. 
the development agenda places special emphasis on Articles 7 and 8 of the TRIPS Agreement. These provisions deal with the objectives of the TRIPS Agreement and point to the need for the international transfer of technology and to the promotion of public policy objectives of socioeconomic and technological development. It is the aim of the WIPO Development Agenda to make sure that all future WIPO initiatives reflect these TRIPS objectives:

First, these provisions place the protection of intellectual property rights in the context of a balance of rights and obligations of producers and users of technical knowledge. This places a special emphasis on the promotion of technological innovation and the transfer and dissemination of technology in a manner beneficial to social economic welfare.

Second, these provisions recognise that WTO Members are entitled to a certain degree of flexibility when it comes to the protection of public health and nutrition, and the promotion of public interest in sectors of vital importance to their socio-economic and technological development.

Third, the provisions recognise that members may take appropriate measures to prevent the abuse of intellectual property rights or practices that restrain trade or adversely affect technology transfer.

\section{Plan}

In the speech that follows, I will introduce to you the content of the Development Agenda and the role and place of the WIPO and the WTO in international standard setting for intellectual property. In this light I will discuss the flexibilities that developing countries are seeking in implementing and interpreting the TRIPS Agreement. This so-called "rational and humane policy" should serve to meet the needs of developing nations when it comes to public and health policy, innovation and technology transfer. By means of examples involving compulsory licensing for essential drugs and recent enhancements of the copyright system, I will show that the Western world is undermining the Development Agenda by introducing so-called TRIPS-plus obligations through the WTO system and bilateral Free Trade Agreements (FTAs) and Bilateral Investment Treaties (BITs). 3

In conclusion I will provide examples how, for the purpose of

3. See www.bilaterals.org. 
furthering investment in innovation and technology transfer to the benefit of developing countries, use is made of the existing IPR framework and how minor amendments could even yield more results.

\section{The Development Agenda}

The Development Agenda is about finding flexibility in the implementation of TRIPS obligations but also about balancing the monopoly of the intellectual property rightholder with the interests of third parties and of society as a whole. Flexibility is, however, something that sits uneasy with the current trend in intellectual property policy. This trend has been one of maximalization of rights to stamp out piracy and one of harmonization to provide a one-size fits all level playing field of rights. Flexibility to curb the full exercise of the intellectual property monopoly to accommodate the interests of users, competitors or developing countries is not popular among industrialists. In a recent interview Bill Gates even went so far as to say that restricting intellectual property rights is tantamount to communism:

"... [Olf the world's economies, there's more that believe in intellectual property today than ever. There are fewer communists in the world today than there were. There are some new modern-day sort of communists who want to get rid of the incentive for musicians and moviemakers and software makers under various guises. They don't think that those incentives should exist.

And this debate will always be there. I'd be the first to say that the patent system can always be tuned -- including the US patent system. There are some goals to cap some reform elements. But the idea that the United States has led in creating companies, creating jobs, because we've had the best intellectual-property system -- there's no doubt about that in my mind, and when people say they want to be the most competitive economy, they've got to have the incentive system. Intellectual property is the incentive system for the products of the future." (Bill Gates, January 2005) 4

4. Gates, 'Restricting IP rights is tantamount to communism', interview with Kanellos, CNET News.com, January 06, 2005, available at insight.zdnet.co.uk/software/windows/0,39020478,39183197,00.htm. 
This statement is testament to the idea that stronger IPR automatically lead to more innovation and that one uniform -read USsystem of rights is superior.

A recent World Bank publication on Intellectual Property and Development,5 however, shows that neither strong IPR, nor bilateral investment or free trade agreements automatically yield an increase in technology transfer and foreign direct investment (FDI). 6 Figures show that countries with weak protection or enforcement of IPR like Brazil and China have been more successful in attracting FDI than many developing countries that have made strong IPR central to their development strategy.7 Brazil and China are high growth, large market economies with an increasingly adequate regulatory system involving taxes, investment regulations, production incentives, trade policies and even a hint of competition rules. The strength of IPR protection is clearly not the only factor in investment decision making. Empirical economic studies show that the relationship between IPR and FDI in developing countries varies highly in respect of industry type, the stage of economic development and the natural and labour resources of the country in question. Econometric evidence of positive effects of strong IPR on FDI and technology transfer is not conclusive. ${ }^{8}$ Strengthening IPR is therefore mostly seen as a signal indicating that a country is willing to provide a more business-friendly environment. It is clear that IPR protection should not be detrimental to follow-on investors and creators. This requires careful definitions on the scope of protection provided by IPR, sensible fair use exceptions that allow certain uses related to teaching, research and private use of protected materials and a balanced compulsory licensing regime, making essential patents and protected works available to competitors and follow-on creators against reasonable royalty rates.

5. Fink/Maskus (eds.), Intellectual Property and Development - Lessons form Recent Economic Research (2005, New York, World Bank/Oxford University Press). See also Braga/Fink/Sepulveda, Intellectual Property Rights and Economic Development, World Bank Discussion Paper No. 412 (2000, Washington, World Bank).

6. Correa, Bilateral investment agreements: Agents of new global standards for the protection of intellectual property rights? (2004, GRAIN) at 3, available at www.grain.org.

7. Maskus, 'The Role of Intellectual Property Rights in Encouraging Foreign Direct Investment and Technology Transfer', note 5 at 54, where examples cited comprise SubSaharan Africa and Eastern Europe.

8. Ibid. at 63-66. 
So far the likes of Bill Gates have been extremely successful in getting their point across. The protection of databases, the legal recognition of digital rights management that limit fair use, 9 the protection of gene sequences for the purpose of diagnostic testing, the patenting of business methods and software are but a few examples of new standard setting that may lead to the de facto protection of ideas and facts, as opposed to the protection of innovation and original expression.

Prior to this, the entry into force of the TRIPS Agreement ${ }^{10}$ had already strengthened the position of intellectual property rightholders by obliging Members to the WTO to adopt minimum standards for protection and provide effective enforcement measures. Since its adoption in 1994 the TRIPS Agreement has become the de facto norm that shapes multilateral, regional, bilateral and national intellectual property laws and practices. It is the basis for all current and future standard setting in the area of IPR.

Further development of IPR protection based on TRIPS Agreement obligations is controversial. A combination of multilateral and bilateral agreements is widening the scope of IPR even more. These BITs or FTAs permit developed countries to use their considerable economic leverage comprising FDI or market access to influence the domestic economy of developing countries. When IPR provisions are included, these agreements are referred to as TRIPS-plus agreements and they can have serious adverse effects on the public interests in developing countries.

An authoritative UK Government Commission on Intellectual Property Rights has noted that introducing higher standards of protection and enforcement of IPR already put a considerable strain on the resources and economies of developing countries. ${ }^{11}$ Further increases could have a

9. Klein/Lerner/Murphy, 'The Economics of Copyright "Fair Use" in a Networked World', American Economic Review, May 2002 (Papers and Proceedings), 92(2), pp. 205-8.

10. The TRIPS Agreement was adopted as part of the Final Act of the Uruguay Round of Trade Negotiations in 1994. See www.wto.org for the full text of the Agreement.

11. Commission on Intellectual Property Rights, Integrating Intellectual Property Rights and Development Policy (2002, London, Commission on Intellectual Property Rights). Bilateral agreements entered into between the EC and their Member States and various partners require these partners to ensure adequate and effective protection of intellectual property rights "in conformity with the highest international standards", see Drahos, Developing Countries and International Intellectual Property Standard-Setting 14-18 (2002), study prepared for the UK Commission on Intellectual Property Rights, all available at www.iprcommission.org. 
negative impact on agriculture, education, public health, innovation and technology transfer and commonly raise the cost of administration and enforcement for developing nations.

Still,TRIPS-plus standards are now a permanent fixture in international trade, as they are integral to many bilateral trade and investment agreements. ${ }^{12}$ Furthermore, WIPO's efforts to develop and promote IPR have more TRIPS-plus overtones than mere TRIPS implementation assistance would require. ${ }^{13}$

From its inception in 1970 and subsequent status as an agency of the United Nations system of international organisations, WIPO has played a central role in the administration of intellectual property Unions and the promotion of the protection of intellectual property ${ }^{14}$ and currently has 179 members. The arrival in 1994 of WTO as the new kid on the block has prompted WIPO to reassess its role. Gone was the possibility for members to pick and choose intellectual property regimes and enforcement standards that the WIPO had on offer. Gone was the possibility of membership without effective enforcement. The TRIPS Agreement galvanised both minimum norms of protection and enforcement. WIPO was in danger of becoming sidelined.

To provide a basis for a sensible division of tasks and competences, a cooperation Agreement was reached with the WTO in 1995. Under it, WIPO now also provides technical assistance for TRIPS implementation to developing country members of the WTO. Providing assistance is after all one of the areas in which WIPO is specialised. In many ways this has become a lifeline for WIPO, which is now able assist the WTO by offering expertise in the area of intellectual property law so as to ensure a successful implementation of the TRIPS Agreement. It also enables WIPO to continue to be engaged in the spread of its own WIPO Copyright and Performances and Phonograms Treaties and the further development of new intellectual property initiatives, being most notably the overhaul of the Patent Cooperation Treaty and the beforementioned inception of a Substantive Patent Law Convention.

\footnotetext{
12. Vivas-Eugui, Regional and Bilateral Agreements and a TRIPS-plus World: the Free Trade Area of the Americas (FTAA), TRIPS Issues Papers No 1 (2003 QUNO/QIAP/ICTSD, Geneva).

13. Musungu/Dutfield, Multilateral Agreements and TRIPS-plus World: The World Intellectual Property Organisation (WIPO) (2003, QUNO/OIAP/ICTSD, Geneva).

14. Vide Art. 3 and 4 of the WIPO Convention.
} 
Yet this newfound role of WIPO as the ambassador of the TRIPS Agreement has also made WIPO more vulnerable to criticism over all activities that they undertake in respect of furthering the acceptance and development of IPR. It is against this backdrop that international standard setting leads to international trade disputes.

All these developments have prompted a debate on the negative impact that raised IPR and TRIPS-plus agreements may have for developing countries. The issues are too numerous to cover within the scope of this lecture, but it suffices to say that TRIPS-plus will stretch the scarce resources of developing nations even further. I will just mention the issue of protection of Geographical Indications for wines and spirits, and other agricultural products or handicraft items, 15 the protection of traditional knowledge and folklore,16 establishing collecting rights societies in developing countries, 17 protection of plant varieties and biodiversity, ${ }^{18}$ and the patenting of biological material. ${ }^{19}$

I will therefore confine myself to two detailed examples illustrating

15. Heath, 'Geographical Indications: International, Bilateral and Regional Agreements'; Kamperman Sanders, 'Future Solutions for Protecting Geographical Indications Worldwide'; and Corte-Real, 'The Conflict Between Trade Marks and Geographical Indications - The Budweiser Case in Portugal', all in Heath/Kamperman Sanders (eds.), New Frontiers of Intellectual Property (2005, Oxford/Portland, Hart).

16. Bachner, 'Back to the Future: Intellectual Property Rights and the Modernisation of Traditional Chinese Medicine'; Antons, 'Traditional Knowledge and Intellectual Property Rights in Australia and Southeast Asia'; Gray, 'Maori Culture and Trade Mark Law in New Zealand', all in Heath/Kamperman Sanders (eds.), New Frontiers of Intellectual Property (2005, Oxford/Portland, Hart).

17. Schlatter, 'Copyright Collecting Societies in Developing Countries: Possibilities and Dangers', in Heath/Kamperman Sanders (eds.), New Frontiers of Intellectual Property (2005, Oxford/Portland, Hart).

18. Heath, 'Plant Varieties, Biodiversity and Access Rights'; Mo, 'Protection of Plant Varieties in Greater China'; Donavanik, 'Plant Varieties and Access Rights in Asia and the South', all in Heath/Kamperman Sanders (eds.), Industrial Property in the Bio-Medical Age (2003, The Hague/London/New York, Kluwer Law International).

19. Llewelyn, 'Perspectives on Patenting Biological Material', Sherman, 'Biological Inventions and the Problem of Passive Infringement', all in Heath/Kamperman Sanders (eds.), Industrial Property in the Bio-Medical Age (2003, The Hague/London/New York, Kluwer Law International); Hubicki/Sherman, "Terminator Genes as "Technical" Protection Measures for Patents?', in Heath/Kamperman Sanders (eds.), New Frontiers of Intellectual Property (2005, Oxford/Portland, Hart). 
the Development Agenda's concerns. First, the contentious issue of access to essential medicine by means of compulsory licensing, which still is a cornerstone of the WIPO Development Agenda.

Second, the issue of how raised standards on copyright may negatively affect follow-on investment and creativity in downstream markets. This demonstrates that there is a more fundamental problem in international standard setting, namely that of raising IPR levels of protection, while omitting to also to address the issue of user rights and competition concerns.

\section{Access to essential medicine}

Compulsory licensing of patented pharmaceuticals has been a hot topic for quite some time. ${ }^{20}$ Most notably the issue of providing access for the poor to drugs to combat AIDS made headlines in the global media and was subject of intense lobbying at the WTO. Governments of South Africa and Brazil, and major drugs companies together with industrialized nations found one another on opposite sides of the fence. If anything, the media coverage has also made the general public aware that drugs companies prefer to target the tourists rather than the developing nations they visit in increasingly greater numbers when it comes to making available much-needed medication for diseases such as malaria, tuberculosis and HIV. These three diseases alone kill 5 million people every year. ${ }^{21}$ Although less than $5 \%$ of the drugs on the World Health Organization (WHO) Essential Drugs List22 are patented23

20. See also Kamperman Sanders, 'Patents - Antitrust, Compulsory Licensing and Research Exceptions', in Heath/Kamperman Sanders (eds.), Industrial Property in the Bio-Medical Age (Kluwer Law International, 2003), 163-84; and 'Compulsory Licensing and Public Health', 11 MJ 4 (2004) 337-46.

21. See AIDS Epidemic Update December 2004, UNAIDS/O4.45E (2004, UNAIDS/WHO), available at www.unaids.org.

22. See www.who.int/medicines/organization/par/edl/procedures.shtml for the selection criteria of essential medicines, which do not include the patent status of the drug in question, but does give consideration to cost, thus potentially excluding therapeutically important, but expensive drugs, and for the list see mednet3.who.int/eml/eml_intro. asp; See also Velásquez, 'Phamaceutical Patents and Accessibility to Drugs', Revue Internationale de Droit Economique Special Edition: Pharmaceutical Patents, Innovations and Public Health (2001), 41 and Dumoulin, 'Patents and the Price of Drugs', Revue Internationale de Droit Economique Special Edition: Pharmaceutical Patents, Innovations and Public Health (2001), 49.

23. IFPMA Press Release, Geneva, 20 December 2001, available at www.ifpma.org. 
and patent protection in many developing countries is less stringent than TRIPS otherwise requires, 24 the drugs are still not available. It is estimated that 2 billion people cannot get adequate treatment. 25 Lack of distribution channels and high cost of drugs relative to the gross domestic product (GDP) and average wage make up half of the explanation why this is so. When it comes to the availability of the latest, more effective, or complex drugs, patent rights and the lack of production facilities make up the other half. Increasingly traditional producers and suppliers of cheap generic drugs such as India, the world's leading supplier of generic medicines, ${ }^{26}$ have been under pressure 27 to adopt TRIPS compliant patent acts that protect pharmaceutical products, processes, and products directly obtained by use of this patented process. ${ }^{28}$ India is also a nation where as high as one in seven people may be infected with HIV. 29 A recently adopted 30 Indian patent act will provide heightened protection to medicines invented after the implementation date, but also those that have been patented outside of India since January 1, 1995. According to TRIPS31 India was required to establish a "mailbox" when it became a member of the WTO. Foreign applicants could already file patents between 1995 and 2005 for later consideration. There are some 4,000 patent applications for medicines that are now waiting to be examined by the Indian Patent Office.

24. The Doha WTO Ministerial Declaration on TRIPS and Public Health of 14 November 2001 (WT/MIN(O1)/DEC/2) reiterates that the least developed members are exempted from implementing, employing and enforcing pharmaceutical product and test data protection and may refrain from granting exclusive marketing protection during the period patent protection is not provided until 1 January 2016, see www.wto.org.

25. See www.europa.eu.int/comm/trade/issues/global/medecine/index_en.htm.

26. $66,7 \%$ of India's drug exports go to developing countries.

27. See report of the WTO Dispute Settlement Body Panel on India - Patent Protection for Pharmaceutical and Agricultural Chemical Products, WT/DS79/R of 24 August 1998.

28. Patents Bill (Bill No. 32-C of 2005), of which TRIPS compliance is still an issue.

29. On the contentious issue whether India is the most HIV-dense country see www.theglobalfund.org and HIV is "out of control" in India', news.bbc.co.uk/1/hi/world/south asia/4461999.stm and 'India rejects HIV infection claim', news.bbc.co.uk/1/hi/world/ south_asia/4463899.stm See also Médecins Sans Frontières www.msf.org/countries India.

30. The bill was passed by the Indian parliament in March 2005.

31. Art. $70(8)$. 
Patents eventually granted may affect generics currently available on the market, unless they are made subject to a compulsory licence.

\section{Compulsory Licensing and the Flexibility of the TRIPS Agreement}

The TRIPS Agreement offers WTO members a broad discretion on government use of compulsory licensing. There are no limitations on the grounds upon which a government can authorize use of a patent by third parties. Grounds explicitly mentioned in Art. 31 TRIPS are: national emergency, anti-competitive practices, public non-commercial use and dependent patents. Further grounds can be found in Art. $8(1)$, which allows members to adopt measures necessary to protect public health and nutrition, and to promote the public interest in sectors of vital importance to their socio-economic and technological development. Furthermore Art. 8(2) permits members to take necessary measures to prevent the abuse of IPR by right holders and practices that unreasonably restrain trade or adversely affect the international transfer of technology. There are, however, a number of procedural requirements that can be summarized as follows:

1. Cases have to be judged on their individual merits, thus excluding blanket advance approval for patents in a particular field of technology; 32

2. Prior to authorizing third party use there should be an effort to negotiate a voluntary licence on reasonable commercial terms;

3. Government must provide for adequate remuneration, taking into account the economic value of the authorization; and

4. Use shall be authorized predominantly for the supply of the domestic market;

5. The scope and duration of the licence is limited to the purpose for which it was authorized, a requirement which is supplemented by the 'Intel clause', limiting the compulsory licensing of semiconductor technology to public non-commercial use and judicial remedies for anti-competitive behaviour;

6. Licences must be terminated if and when the circumstances, which led to it, cease to exist and are unlikely to recur.

32. Further reinforced by Art. $27(1)$, which states that patents shall be available and patent rights enjoyable without discrimination as to the place of invention, the field of technology and whether products are imported or locally produced. 
Exemptions can be found in Art. 31(b), which allows a waiver of the requirements for negotiation for a voluntary licence on reasonable commercial terms in case of

1. A national emergency or other circumstances of extreme urgency; or

2. In cases of public non-commercial use.

In short, the TRIPS rules on compulsory licensing seemingly already offer the necessary flexibility that proponents of the WIPO Development Agenda seek.

However, nations, most notably Brazil and South Africa, trying to use this flexibility for the purpose of supplying generic anti-retroviral AIDS drugs produced under (threat of) compulsory licences, found that their interpretation of this scope of the flexibility that TRIPS offers differs from western notions for fair licensing.

The United States in particular were quick to point to the general nature of the compulsory licensing provisions in the patent statutes of these countries and in 2001 took action against Brazil before the WTO.33 The USA complained:

'Brazil has asserted that the U.S. case will threaten Brazil's widely-praised anti-AIDS program, and will prevent Brazil from addressing its national health crisis. Nothing could be further from the truth. For example, should Brazil choose to compulsory licence anti-retroviral AIDS drugs, it could do so under Section 71 of its patent law, which authorises compulsory licensing to address a national health emergency, consistent with TRIPS, and which the United States is not challenging. In contrast, Section 68 - the provision under dispute - may require the compulsory licensing of

33. On 1 February 2001, a WTO panel was established to hear the case (WT/DS199/1). The U.S. position was that the compulsory licensing provision for non-working is in violation of Art. 27(1) TRIPS, which prohibits Members of the WTO from requiring the local production of the patented invention as a condition for enjoying exclusive patent rights. The United States asserted that the "local working" requirement contained in the Brazilian Patent Act can only be satisfied by the local production - and not the importation - of the patented subject-matter. This position is fuelled by the impression that working of the patent needs to take place in the territory of Brazil. Furthermore, the U.S. takes issue with the fact that failure to work the patent also comprises incomplete manufacture of the product or a failure to make full use of the patented process. 
any patented product, from bicycles to automobile components to golf clubs. Section 68 is unrelated to health or access to drugs, but instead is discriminating against all imported products in favour of locally produced products. In short, Section 68 is a protectionist measure intended to create jobs for Brazilian nationals. 34

In the ensuing public relations battle Brazil put itself ahead of the game in that it capitalized on the AIDS drugs patent dispute in South Africa35 and brought its successful national STD/AIDS programme to the attention of the world. 36 Brazil even managed to get a resolution adopted by the UN Commission of Human Rights on the right of access to medication. 37 The 53-member body passed the resolution by a 52-0 vote, with the United States abstaining.

At the WTO Doha Ministerial Conference of November 2001 in Quatar, consensus on the compulsory licensing issue was seen as imperative for the successful conclusion of a new round of world trade negotiations. $3^{8}$ Ironically the Anthrax crisis in the USA and the reaction of the US government in face of this national emergency to obtain the

34. U.S. Special 301 report, 2001, www.ustr.gov/enforcement/special.pdf on the dispute before the WTO with Brazil.

35. See Seeman 'Patently Wrong', National Review, 21 March 2001, www.nationalreview. com/nr_comment/nr_commentprinto32101a.html; Mutetwa, 'HIV/AIDS: is Zimbabe doing enough?', Financial Gazette 26 April 2001, www.fingaz.co.zw/fingaz/2001/April/ April 26/1429.shtml, Reuters, 'Cuba Backs Brazil in AIDS Drugs Patent Dispute', 3 April 2001, and 'Cuba Seeks Third World Challenge to Patent Rules', news.findlaw.com/legalnews/s/20010323/cubausapatents.html.

36. See Commission on Intellectual Property Rights, Integrating Intellectual Property Rights and Development Policy (2002, London, CIPRs) at 43, available at www.iprcommission. org.

37. See the resolution adopted by the UN Sub-Commission on the Promotion and Protection of Human Rights, Intellectual Property Rights and Human Rights, UN Doc. E/CN.4/Sub.2/ Res/2000/7. See also UN Commission on Human Rights Resolution, Access to medication in the context of pandemics such as HIV/AIDS, UN Doc. E/CN.4/RES/2001/33, of 23 April 2001, which was proposed by Brazil. Available at www.unhchr.ch/.

38. Moore, former director-general of the WTO, indicated in a statement that 'resolving the TRIPS and public health issue might be the 'deal-breaker' for a new trade round', see Banta, 'Public Health Triumphs at WTO Conference', 286 Journal of the American Medical Association, 2655 (2001), 2656, available at jama.ama-assn.org/issues/v286n21/fpdf/ jmn1205.pdf. 
drug CIPRO at the lowest price possible was a godsend for developing countries. They felt empowered to push within the WTO for a deal on compulsory licensing.

Due to the continuing media exposure of the lack of availability of antiretroviral AIDS drugs for the poor, of the fact that profit margins for Big Pharma are the highest of any industry,39 and of the Anthrax crisis in the USA 40 a breakthrough was possible in the post 9/11 world. The result was a joint declaration on the TRIPS Agreement and Public Health. 41 The Ministerial Declaration amounts to an understanding that members will not bring action under the WTO Dispute Settlement Understanding over compulsory licensing of essential patented drugs. 42 It also reiterates that the least developed country Members 43 will not be obliged, in respect to pharmaceutical products, to implement the patent section 44 or to enforce rights provided for under these sections before 1 January 2016, thus alleviating any pressure on the compulsory licensing issue.45 The Ministerial Declaration hinges on the interpretation of TRIPS

39. In terms of profit ranked by percentage return on revenues, pharmaceuticals rank first at over $18 \%$. By means of comparison, commercial banks achieve rates of $14 \%$, mining and crude oil production $9 \%$, household and personal products $8 \%$, and insurance and securities $7 \%$. See 362 New Internationalist (2003), available at www.newint.org.

40. See 'Double Standards', Nature, 1 November 2001, vol. 4141 at 1: 'The Bush administration ... proceeded to extract agreement from Bayer to supply the drug at one-fifth of its previous price. The health secretary, Tommy Thompson, even boasted that the threat of compulsory licensing had helped to clinch the deal.'

41. Adopted on 14 November 2001, WT/MIN(01)/DEC/2, 20 November 2001.

42. Vandoren, 'Médicaments sans Frontières? Clarification of the Relationship between TRIPS and Public Health resulting from the WTO Doha Ministerial Declaration', 5 Journal of World Intellectual Property (2002); and Abbott, 'The TRIPS Agreement, Access to Medicines, and the WTO Doha Ministerial Conference', 5 Journal of World Intellectual Property (2002).

43. For a list of least developed countries see www.unctad.org/Templates/webflyer.asp?do $\mathrm{cid}=2929$ \& intltem $\mid \mathrm{D}=1634$ \&lang $=1$.

44. Section 5 TRIPS Agreement.

45. On the issue of the role of the patent system as a motivator or hindrance to innovation in the pharmaceutical area see Muennich, 'Pharmaceutical Patents and Availability of Drugs', Revue Internationale de Droit Economique Special Edition: Pharmaceutical Patents, Innovations and Public Health 73 (2001) and Mossinghoff, 'The Importance of Intellectual Property Protection to the American Research-Intensive Pharmaceutical Industry', 31 Columbia Journal of World Business 38 (1996). 
Article 8(1) and its exception for the institution of measures necessary 46 to protect public health that are consistent with the TRIPS provisions. 47 In the face of adversity (the U.S. and Big Pharma tried to limit the scope of the Declaration to drugs for the treatment of HIV/AIDS, tuberculosis and malaria) the WTO members took some two years to agree on measures that would lead to a satisfactory arrangement to give effect to the Declaration. The supply of essential drugs under compulsory licences to least-developed WTO members and WTO members with insufficient or no manufacturing capacity in the pharmaceutical sector was finally guaranteed in the WTO General Council Decision of 30 August 2003 on the Implementation of Paragraph 6 of the Declaration of the TRIPS Agreement and Public Health. 48 The Decision will see the WTO begin to routinely review the issuance of individual licences for pharmaceutical products and it will look at the terms of individual licenses. It will evaluate the basis for deciding manufacturing capacity is insufficient, or review any of the new terms and obligations for the issue of compulsory licences of patents on medicinal products. The conditions for a compulsory licence will then also include measures to ensure tiered pricing and measures on parallel imports. This means that cheap medicine destined for developing nations is not imported back to developed nations to be sold at a premium price.

46. See Canada, where stockpiling of drugs in the last six months of patent term was permitted. Rogers, 'The Revised Canadian Patent Act, the Free Trade Agreement, and Pharmaceutical Patents: An Overview of Pharmaceutical Compulsory Licensing in Canada', [1990] 10 EIPR 351. See WTO Dispute Settlement Body Panel Report in Canada Patent Protection of Pharmaceutical Products WT/DS114/R of 25 April 2000. Canada had to comply with the DBS's rulings and recommendations by 12 August 2001, abolishing the stockpiling practice.

47. See Art. 27(1) TRIPS, which states that any measures adopted cannot discriminate as to the place of invention, the field of technology and whether products are imported or locally produced; and also Art. XX of GATT 1994, indicating that any measures under TRIPS necessary to protect health also cannot amount to 'arbitrary or unjustifiable discrimination between countries where the same conditions prevail, or a disguised restriction on international trade'.

48. WT/L/540 of 2 September 2003. 
We are currently witnessing the first proposals on the implementation of the WTO Decision in the EU and Canada.49 These proposals provide for a two-pronged approach to the issue of compulsory licensing. First, that essential medicine may be produced under compulsory licence in the EU and Canada for the purpose of export to WTO members with insufficient production capacity. Second, that these drugs are so distinctive that customs can easily detect illegal parallel re-importation. The EU and Canada seem intent on protecting their own pharmaceutical industry base by allowing production of generics in the EU and Canada under strict conditions by making use of the WTO system. European and Canadian production and control over distribution of drugs will after all prevent technology transfer to developing countries.

\section{Data Exclusivity}

The USA appears to regard the multilateral trade system with flexible standards on compulsory licensing of pharmaceuticals as being contrary to US interests. It bypasses the WTO system that it was previously a major advocate of by entering in bilateral trade agreements. Since the establishment of the WTO in 1995, the United States have entered into more than 40 BITs and FTAs,50 most which contain a particular USstyle interpretation on appropriate standards for exclusivity of data51

49. Proposal for a Regulation of the European Parliament and of the Council on compulsory licensing of patents relating to the manufacture of pharmaceutical products for export to countries with public health problems COM (2004) 737; Similarly see Canadian Bill C-9, An Act to amend the Patent Act and the Food and Drugs Act (The Jean Chrétien Pledge to Africa), 3d sess., 37th Parl., 2004 and the 'Regulations Amending the Food and Drugs Regulations, (1402 - Drugs for Developing Countries', Canada Gazette Vol. 138, No. 40 - October 2, 2004, pp. 2748-2760.

50. Signed US FTAs comprise Jordan, Chile, Singapore, Guatemala, El Salvador, Nicaragua, Honduras, Costa Rica, Australia, Morocco, the Dominican Republic and Bahrain. A further FTA with the Central American states as a group (CAFTA) is in the process of being ratified by the US Congress.

51. Art. 39(3) TRIPS provides: "Members, when requiring, as a condition of approving the marketing of pharmaceutical or of agricultural chemical products which utilise new chemical entities, the submission of undisclosed test or other data, the origination of which involves a considerable effort, shall protect such data against unfair commercial use. In addition, Members shall protect such data against disclosure, except where necessary to protect the public, or unless steps are taken to ensure that the data are protected against unfair commercial use." 
necessary to obtain marketing approval test results for new drugs. 52

In order to obtain marketing authorisation for a pharmaceutical product, regulatory standards attesting that the product is clinically proven to be safe and effective have to be met. Drugs are therefore subject to controlled trials that generate the data necessary to satisfy national or regional regulators. Medical trials are expensive and require substantial technical skill and expertise. According to the TRIPS Agreement, the investment and skill necessary to conduct medical trials has to be safeguarded and WTO members have to provide for the protection of this data submitted to regulators. Producers of generic drugs also have to apply for marketing approval. The usual method of obtaining rapid marketing approval is by showing that the generic drug is bio-equivalent to the drug that has already been approved and that the generic producer is capable of producing the drug at consistent quality standards. The test for consistency in production requires the generic producer to breach any patent that may still be valid. Whether there is an exception for manufacturers of generic drugs to engage in clinical trials prior to patent expiry is not harmonised by the TRIPS Agreement and standards and procedures vary from jurisdiction to jurisdiction. The lack of harmonisation in the area of patent licensing for the purpose of clinical testing is compounded by the existence of data exclusivity, as this may force subsequent applicants for marketing approval to generate their own clinical data independently and at their own expense. Data exclusivity therefore not only raises the cost of the generic product, but serves as a protection mechanism in addition to patent protection, since there is limited value in holding a compulsory licence if the holder nevertheless has to spend time and money generating its own clinical trial data in order to obtain marketing approval.53

In most cases, a bilateral agreement with the United States obliges the other signatory to provide a period of data exclusivity of between five and ten years. A common element is that if medical trial information submitted in the first country of marketing approval is relied on to obtain marketing approval in another country, the term of data

52. On data exclusivity see Brazell, 'A World United? The US Approach to the Protection of Regulatory Data', (2004/2005) 168 Patent World, 23-25.

53. On clinical trials see A. Kamperman Sanders, 'Patents - Antitrust, Compulsory Licensing and Research Exceptions' in Heath/Kamperman Sanders (eds.), Industrial Property in the Bio-Medical Age (2003, The Hague/London/New York, Kluwer Law International). 
protection of the first country is recognized in the other. Furthermore, patent holders are usually to be notified if producers of generic drugs attempt to obtain marketing approval prior to patent expiry, enabling patent holders to take immediate infringement action should medical trials be conducted or production and stockpiling of generics be undertaken prior to patent expiry. This turns the regulatory authorities that deal with marketing approval for drugs into watchdogs for the pharmaceutical industry. Some FTAs even require signatories to provide for data exclusivity for all pharmaceutical products, even if these do not incorporate new chemical entities.54

What is worrying is that the EU also seems to have picked up on the possibility of using the provisions on data exclusivity as a means of mitigating the effects of compulsory licensing of pharmaceuticals. The EU is actively pursuing the issue of data exclusivity within the framework of the Cotonou Agreement with African, Caribbean and Pacific (ACP) countries. 55

The fact that the issue of data exclusivity has not been included in the Doha Declaration now appears to be an oversight that is exploited to foreclose on the flexibility agreed to in the Doha Declaration. The scope for compulsory licensing remains severely limited if data exclusivity rules preclude a rapid response to a national emergency. No doubt Big Pharma56 is following these developments with glee. With a global system of protection of data exclusivity in place they no longer need to rely on patents. Government regulators will ensure that suppliers of medical trial data retain a de facto market monopoly over the drug they have marketed. Government regulators will furthermore give Big Pharma early warning of any attempt at producing or marketing generic drugs close to patent expiry, so that patent infringement action can still be brought in time. The cost for all this extra work for regulators will be borne not by Big Pharma, but by nations under the obligation to provide data exclusivity.

Let me now turn to my second example, for which we turn to the domain of copyright.

54. US-Singapore FTA, Article 16(8) and draft FTAA Section B(2)(j), Art. 1.

55. See the Third World Network Africa website at twnafrica.org/news_detail. asp?twnID $=788$.

56. The Big Pharma top 10 list comprises Pfizer, GlaxoSmithKline, Merck, AstraZeneca, Johnson \& Johnson, Novartis, Bristol-Myers Squib, Pharmacia, and Weyth. 


\section{Incentives for innovation}

IPR create a market for inventions, artistic works, or distinctive signs. This market enables the rightholder to exercise control over the first sale of an industrial or intellectual creation, or a product that embodies or carries this creation, so that he is able to reap the rewards of his innovation, creation, or marketing effort. IPR also offer the possibility to control the use of the protected intellectual asset after the first sale. This form of licensing power over downstream markets may be detrimental to welfare, 57 because it may limit the development of downstream innovation.

A striking example of this problem is reflected in the discussion on the legality of filesharing technology, such as Kazaa, Morpheus, Grokster and other non-centralised peer-to-peer networks. $5^{8}$ The US Supreme Court is currently considering the legality of filesharing technology in the case of MGM v. Grokster.59 The discussion is similar to that on the legality of video recorders in the previous century, ${ }^{60}$ namely whether producers of copyright content should be able to control the market of the technology used to reproduce and distribute this content even if this technology is innovative and also has non-infringing purposes. The example from the past concerned the use of the video recorder to view recorded TV programmes at a time that better suits our busy lifestyles. ${ }^{61}$

57. Boldrin/Levine, 'The Case Against Intellectual Property', American Economic Review, May 2002 (Papers and Proceedings), 92(2), pp. 209-12.

58. See the pending case of MGM v. Grokster, which was heard by the US Supreme Court on March 29, 2005. In MGM v. Grokster, 380 F.3d 1154 (9th Cir. 2004), the Ninth Circuit found that $\mathrm{P}_{2} \mathrm{P}$ file-sharing software is capable of, and is in fact being used for, noninfringing uses. Relying on the Betamax precedent of Sony Corp. of America v. Universal City Studios, 464 U.S. 417 (1984), the court ruled that the distributors of Grokster and Morpheus software cannot be held liable for users' copyright violations. See also Grokster I, 259 F. Supp. 2d at 1031-33.

59. See in this respect also the opposing briefs by numerous law and economic professors in the Supreme Court case of MGM v. Grokster on behalf of either the respondent (Grokster) or the petitioners. All available at www.eff.org/IP/P2P/MGM_v_Grokster/.

6o. Sony Corp. of America v. Universal City Studios, 464 U.S. 417 (1984).

61. Upon the introduction of Microsoft's Media Center software, Bill Gates suggested that the technical possibility offered by digital video recorders to automatically remove advertising from recorded content is infringing rights of broadcasters and advertisers. See his interview for the Hollywood Reporter on the way Microsoft will ensure that we will continue to receive advertising at www.hollywoodreporter.com/thr/new_media/ article_display.jsp?vnu_content_id=1000671642. 
Now it is the use of software to find and disseminate information of any description using the least bandwidth and distributed computing power.

Increasingly technical protection mechanisms affect what an enduser can or cannot do in respect of information that has been purchased legally, thus limiting previously established user rights, such as making copies for private or educational use. In effect these recognised exceptions and limitations to copyright are curtailed.62 Current broadband access that indeed enables users to conveniently bypass the media industries' old fashioned distribution methods for music and films is predominantly available to 117,6 million households in industrialised nations. Although large-scale copyright infringement through file sharing networks is therefore a problem in the industrialised world, the global copyright system has already been tailored to meet the worries of media industries by means of the WIPO Copyright and Performances and Phonogrammes treaties. These treaties have introduced the right to control communication to the public of copyright works and provide rightholders with the possibility to act against the removal or alteration of digital rights management information, and technical protection mechanisms.

Although not part of the WTO TRIPS Agreement, these WIPO treaties are fast becoming the de facto world standard, not only because countries voluntarily sign up to these agreements, but through inclusion in BITs and FTAs. The United States is exporting its version of the WIPO treaties, the Digital Millennium Copyright Act (DMCA), not because it fulfils the needs of citizens and industry in developing nations, but because of economic and political pressure it can exert through BITs and FTAs. 63

62. See Gordon, 'Fair Use as Market Failure: A Structural and Economic Analysis of the Betamax Case and Its Predecessors', 82 Columbia Law Review, 1600-57 (1982), showing that the US Supreme Court decision in the Betamax case that the sale of Betamax video recorders did not constitute contributory copyright infringement made perfect economic sense because the video recorder has substantial non-infringing uses (like time-shifting) that do not adversely affect the market value of the original copyrighted work. Licensing control of the film studio's over the market for video recorders would stifle technical innovation.

63. See Correa, note 6 above; Drahos, Expanding Intellectual Property's Empire: the Role of FTAs (2003, GRAIN), both available at www.grain.org. 
Criticism against the unilateral focus on strengthening of rights is rife. ${ }^{64}$ The problem stems from the fact that international copyright harmonisation has focussed on the protection of copyright, not on establishing common standards on limitations and exceptions. National law predominantly determines the scope and number of these limitations and exceptions. Limitations and exceptions can be found in statute, as is the case in Europe, or in jurisprudence by means of an intricate case-by-case fair use analysis, as is the case in the USA.

The inclusion of IPR in BITs and FTAs means that countries that lack access to even the most elementary educational materials are confronted with the demand that their copyright statutes are tailored to meet the highest western norm. Exceptions and limitations enabling fair use of copyright works are, however, not part of that international standard setting to the same extent as heightening protection levels are. There is little guidance on the appropriate limitations and exceptions, let alone special concessions for developing countries, other than the WTO-endorsed mantra that the economic interests of rightholders should not be harmed. 65 The fact that the media industry has long been inapt and unwilling66 to replace outdated CD and DVD disc technology by adequate internet distribution methods only reinforces the feeling that stronger IPR merely serve to preserve the stranglehold of western big media industry over new global distribution methods. It is not surprising therefore that developing countries feel they have been forced to adopt a copyright system that enables multinational media conglomerates to maintain a position of global dominance.

Apart from the fact that the United States of America appears to be intent on establishing a new status quo outside of multilateral WTO framework, the problem with this practice is that the DMCA itself is controversial. Many user interest groups in the USA itself, like the Electronic Frontier Foundation argue that the unilateral focus on

64. Boyle, 'A Manifesto on WIPO and the Future of Intellectual Property', 9 Duke Law and Technology Review (2004) 1.

65. See the WTO Dispute Settlement Body Panel Report on United States - Section 110(5) of the US Copyright Act WT/DS160/R of 15 June 2000, providing interpretation on the Berne Three step test dealing with appropriate exemptions to copyright.

66. See Alderman, Sonic Boom - Napster, MP3, and the New Pioneers of Music (2001, Cambridge MA, Perseus); Lessing, Free Culture: How Big Media Uses Technology and the Law to Lock Down Culture and Control Creativity (2004, New York, Penguin). 
strengthening IPR leads to the loss of the traditional balance between rightholders and users underpinning the intellectual property system. They advocate the curbing of IPR by means of enacting stronger user rights in relation to copyright, allowing for compulsory licensing for essential facilities in the media or medical domains, or simply excluding subject matter from patentability. Others simply defend the interest of righholders and claim that IPR are full property rights conferring an absolute monopoly that should not be subject to limitations harming the righholder's interests. The widely diverging beliefs held by either side in this debate can be seen in the briefs submitted to the court in support of the media industry or producers of filesharing technology in the recent US Supreme Court case in MGM v. Grokster. 67 It is clear from these statements of support that even law professors, economics professors and authors of intellectual property treatises cannot agree on appropriate user rights.

\section{The Development Agenda and IPR policy}

The call of the Development Agenda is to come up with a humane policy that takes into account the needs of developing nations. The recognition of access to medicine as a human right was seen as a first step in formulating this humane policy. Yet, the adoption by the UN Commission of Human Rights of a declaration on the right of access to medicine remains merely symbolic if the IPR system remains unclear on the appropriate balance of rights and interests. Rather than looking to other or higher legal principles like human rights 68 to forge humane IPR policy, the IPR system needs to internalise the recognition of the interests of all stakeholders. The recognition of interests of both developed and developing nations is therefore part of a wider concern on the fundamentals of the IPR system. Individual rightholders, consumers, citizens and society at large all share a common interest in innovation and development of and access to industrial and intellectual creativity. WIPO, as the UN's bureau on the development of IPR, should

67. See in this respect also the opposing briefs by numerous law and economic professors in the Supreme Court case of MGM v. Grokster on behalf of either the respondent (Grokster) or the petitioners. All available at www.eff.org/IP/P2P/MGM_v_Grokster/.

68. Geiger, 'Fundamental Rights, a Safeguead for the Coherence of Intellectual Propery Law?' 35 (2004) IIC 268; Ostergard, 'Intellectual Property: A Universal Human Right?', 21 Human Rights Quarterly 1 (1999) 156. 
take a leading role in tailoring the IPR system to accommodate the needs of all stakeholders.

On 4 October 2004 the WIPO General Assembly agreed to adopt a decision to further examine the Development Agenda proposal originally presented by Brazil and Argentina (and subsequently sponsored by many developing countries) to integrate in a more systematic manner the development dimension in all of WIPO's work. Prior to the General Assembly meeting, hundreds of nonprofit organizations, scientists, academics and other individuals had signed the "Geneva Declaration on the Future of WIPO"69 in support of the Development Agenda's aims to engrain in WIPO's policies the practice of using IPR as tools for the development of nations as opposed to the mere safeguard of the interests of individual rightholders. Despite the apparent support in the WIPO General Assembly for the Development Agenda no new bodies to discuss matters raised in the proposal were created, because after all: "WIPO had always been sensitive to the concerns of developing countries". The Development Agenda has not yet died a quiet death, but our patient is seriously ill.

An inter-sessional intergovernmental meeting in the Development Agenda for WIPO was held on 11 to 13 April 2005. Brazil, now heading the "Group of Friends of Development", comprising Argentina, Bolivia, Brazil, Cuba, Dominican Republic, Ecuador, Egypt, Iran, Kenya, Peru, Sierra Leone, South Africa, Tanzania and Venezuela raised the stakes in a more elaborate proposal on the Development Agenda for WIPO.70 This document reads as an indictment of all that is wrong within WIPO. The issue that stands out is WIPO's effort to standardize IPR to the highest norm at the expense of least developed and developing nations. The document reiterates that WIPO should be driven by a policy recognising that:

"Intellectual property should be regarded not as an end in itself, but as a means for promoting the public interest, innovation, and access to science, technology and the promotion of diverse national creative industries - in order to ensure material progress and welfare in the long

69. See www.cptech.org/ip/wipo/futureofwipo.html.

70. Proposal to Establish a Development Agenda for WIPO: An Elaboration of Issues Raised in Document WO/GA/31/11, WIPO document IIM/1/4/ of April 6, 2005, available at wWW. wipo.int. 
run. Promotion of intellectual property protection alone is not sufficient if unaccompanied by policies that respond to the specific development needs of each country." 71

A proposal submitted for discussion by the United Kingdom 72 recognises the needs of least developed and developing countries and points to the burdens associated with TRIPS implementation on these countries. It indicates that there ought to be flexibility to the point of a clear opt out for least developed and developing countries to implement and reform of their IPR system at a pace in line with their rate of development. However, the UK submits that the WTO and not WIPO is the appropriate forum to address these complex issues of technology transfer.

Even more remarkable, given the fundamental criticism and sweeping proposals for change within WIPO that the Group of Friends of Development's paper contain, is the proposal73 from the United States of America for the same meeting. It contains little more than a proposal for the "WIPO Partnership Program". This is an internet clearing house for development hosted by WIPO, which should bring together donors and recipients of IPR development assistance. The rationale for the WIPO Partnership Program is to provide more coordinated technical assistance in the area of IPR development. Could it be that the United States is talking about assistance to further the development of IPR, as opposed to IPR and development? I fear this is indeed the case. A followup meeting is planned for June.

Those who have signed the Geneva Declaration on the Future of WIPO, and I have seen that many colleagues present today have done so, have to rise to the challenge of making sure that the need for a Development Agenda for WIPO is not forgotten. The role of academics in the field is to teach students and to make policy makers aware of the possibilities to redress the balance of the IPR system. Possibilities are manifold and there is a lot of work still to be done.

71. Ibid, p.4.

72. WIPO document IIM/1/5 of April 7, 2005, available at www.wipo.int.

73. WIPO document IIM/1/2 of March 18, 2005, available at www.wipo.int. 
I have four points I would like to raise with you now.

First, governments should be made aware of methods to provide equal access to publicly funded research by stipulating that participating academic and industry partners commit themselves to an "open source" licensing regime. Such a regime should allow partners and third parties to make use of and innovate on the basis of the results stemming from this research on condition that these original results remain free from other IPR.74 In combination with an active policy on technology transfer, open source licensing may be a valuable instrument in providing aid, especially when used to stimulate FDI in startups and joint ventures in developing countries.

Second, policy makers have to be made aware of the fact that strengthening and introducing new IPR like data exclusivity can have surprising and undesired effects. Unless the current IPR incentive structure is changed, access to medicine will continue to be subject to trade disputes over patent protection, compulsory licensing, tiered pricing, parallel importation and data exclusivity. The current WTO General Council Decision on the TRIPS Agreement and Public Health aims to provide tiered pricing of pharmaceuticals. This is a first effort to discriminate between the sale of highly priced commercial pharmaceuticals for the consumer in developed nations and the distribution of essential medicine for HIV/AIDS, malaria, tuberculosis and other tropical diseases to the needy in least developed and developing countries.

It is problematic that $R \& D$ spending for pharmaceuticals to combat many tropical diseases is not a priority, because the expected return on investment is low.

Until Big Pharma is offered real incentives to invest in R\&D of drugs for the poor75 and is offered a way to recoup the investment in patented

74. See the European Commission expert group reports on: IPR Aspects of Internet Collaborations (2001, EUR 19456); Managing IPR in a Knowledge-based Economy Bioinformatics and the Influence of Public Policy (2001, EUR 20066); Role and Strategic Use of IPR in International Research Collaborations (2002, EUR 20230); Strategic Use and Adaptation of Intellectual Property Rights Systems in Information and Communications Technologies-based Research (2003, EUR 20734).

75. Cohen, 'An Epidemic of Neglect: Neglected Diseases and the Health Burden in Poor Countries', 23 Multinational Monitor, No 6 (2002), available at multinationalmonitor. org. 
medicine already on the market, it will continue to use all means to protect its market.76

We also need to accept that under spending in $R \& D$ for diseases affecting least developed and developing nations is comparable to the problems related to $R \& D$ into serious diseases that affect relatively few people. To provide incentives for research in medicine for the cure of rare diseases, so-called Orphan Drugs Acts were enacted in the US,77 Europe,78 and a number of other countries. It is questionable though whether the solution provided by these acts will provide a stimulus for $R \& D$ in tropical diseases where those suffering have severely limited means to purchase the drugs.

In addition to patent protection, Orphan Drugs Acts offer incentives to develop orphan drugs by providing tax benefits, government grants, and a period of 7 to 11 years of market exclusivity. This IPR is available irrespective of the research input actually required to develop and market Orphan Drugs. There is justified criticism that this lack of competition increases orphan drug prices unnecessarily.79

Conversely, an incentive system for R\&D in essential medicines for least developed and developing countries should result in low prices and maximum access to the drugs. It is possible to counterbalance a

76. Weissmann, 'Victory and Betrayal The Evergreen Patent System Pharmaceutical Company Tactics to Extend Patent Protections', 23 Multinational Monitor, No 6 (2002), available at multinationalmonitor.org.

77. US Orphan Drug Act (January 4, 1983), Public Law 97-414; 21 USC 36oee.

This special designation of "orphan drug" is granted if the disease in the population affects less than 200000 people (approximately $0.1 \%$ ) or if no profits cannot reasonable be expected. Benefits include:

- assistance to design research protocols;

- tax credits of $50 \%$ for clinical research for clinical trials undertaken in the US;

- seven years of marketing exclusivity following the marketing authorization;

- funding grants of up to US\$200.000 for clinical research to support development;

- penalty for intentionally false statement of orphan status;

- process patents granted for biotechnology products;

- accelerated approvals.

78. Regulation (EC) No $141 / 2000$ of the European Parliament and of the Council of 16 December 1999 on orphan medicinal products, (2000) OJ L18/1.

79. See the UK House of Commons Health Committee, The Influence of the Pharmaceutical Industry, Fourth Report of Session 2004-05, Volume I, HC 42-I of 05-04-2005, at 32. 
compulsory licence by means of a geographically limited patent term extension certificate for the licensor, provided that it addresses the issue of reasonable royalty payment only. Producers of compulsory licensed generic drugs are then able to reduce the price of drugs in least developed and developing countries further by spreading the payment of royalty fees over a longer period of time, even after the normal date of patent expiry. In return for a term extension the patent holder should be required to plough the proceeds of such a scheme back into $R \& D$ targeting diseases that affect least developed and developing nations most. These specific $R \& D$ programmes would then be much more identifiable for additional public funding by governments, or by aid organisations and charitable institutions. This would make them stakeholders in the development, production and marketing of essential medicine. Such public-private partnerships should be subject to the active policy on technology transfer and open source licensing I spoke of. IPR licensing can therefore be used to make sure that any new patentable invention that is the result of this research is part of a common patent pool to which all stakeholders have guaranteed access. On the basis of this jointly held IPR it is also possible to licence on the basis of tiered pricing regimes, or not to apply for patent rights in developing or least developed nations at all.

Third, patent offices, as keepers of public records, have to fulfil their obligation to society at large in making available up-to-date and current information to the World Health Organisation and recognised aid organisations (like Médecins Sans Frontières) on which medicines are patented, where, and for how long. This means that investment and technology transfer decisions can be made on locating production capacity for generic essential medicine in countries where patent rights are not in force. This brings both drugs and knowledge to the people in need and decreases the need for long and complex distribution channels.

Fourth, local communities in third world countries should be made aware of ways to using the IPR system to their advantage. A perfect example is the recent agreement 80 between six indigenous communities, represented by the Association for Nature and Sustainable Development (ANDES) and the International Potato Centre (CIP) in Peru. The agreement deals with the repatriation, restoration and monitoring 
of agrobiodiversity of native potatoes and associated community knowledge in growing and developing unique potato strains. The International Institute for Environment and Development in London and the Dutch Government supported this initiative. Its objective is to ensure that the genetic resources and knowledge remain under the custody of the communities and do not become subject to IPR held by others. ${ }^{81}$ In effect this means the storing and making available of potato genome information through databases in an effort to destroy the novelty required for patenting genome sequences. The agreement contains provisions on the joint conservation and management of the genetic resources of native potato, equitable benefit sharing of the benefits gained from the use of genetic plant resources for food and agriculture and obligations to develop, record and protect indigenous knowledge related to these genetic resources. The agreement recognises that indigenous people hold a different view of property than westerners do, yet it relies on contract and the IPR system to provide a number of communities with the common ownership and stewardship of genetic resources and indigenous knowledge.

These are merely four exercises in flexibility that show that even the current IPR system can be used as a policy instrument for development. Common or joint ownership of IPR -or dare I say a little bit of modern-day communism- can go a long way in providing incentives for preservation, development and technology transfer.

81. On IPR and investment strategies for agricultural societies see Lele/Lesser/HorstkotteWesseler (eds.), Intellectual Property Rights in Agriculture (2000, Washington, World Bank). 


\section{Dedications}

Mr. Rector Magnificus, ladies and gentlemen,

I have reached the end of my lecture.

I would like to thank the Institute of European Studies of Macau and its partners for the courage in building a bridge from East to West by sponsoring this chair for European and International Intellectual Property Law at Maastricht University. I thank the Executive Board of Maastricht University and the Faculty Board of the Faculty of Law for providing the foundations for this bridge. I am grateful to all of you for the trust you have all placed in me. I will try to meet your high expectations and hope to cross this bridge many times.

I am particularly grateful to Dr. José de Sales Marques, president of the IEEM, for his sound architectural planning, to Mr. Gonçalo Cabral and Ms. Maria do Céu Esteves for their initial groundwork, and to Dr. Christopher Heath, until recently the head of the Asian Department of the Max Planck Institute in Munich, for being my academic travel companion and good friend.

I salute and thank my teachers and supervisors, Professors Willem Hoyng, Alison Firth and Gerald Dworkin for being critically supportive of my early dabblings in intellectual property law and for their continued interest in my career and wellbeing. I remain indebted to all at the Queen Mary Intellectual Property Research Institute in London. Without your friendship and support, my years as a PhD student would have been less colourful.

To all my colleagues at the Faculty of Law, I say thank you for being welcoming and for supporting me. I look forward to working with you in future. Special mention is reserved for Professors René de Groot, Sjef van Erp, Gerrit van Maanen, Kid Schwarz, Aalt Willem Heringa, Peter van den Bossche and for the Director of the Faculty, Appie Luermans. Working with you in academic and administrative pursuits is always a pleasure. Your drive and expertise has instilled in me the desire to continuously strive for higher standards in education and research. 
To all speakers at IEEM seminars in Macau and IPR conferences here in Maastricht I give my sincere gratitude for sharing knowledge and for contributing to a number of fine books. It is only fitting that Mr. Bentham Fong, Ms. Beatrice Lam and all staff at IEEM are acknowledged with the same gratitude for running such a smooth operation and particularly for making speakers and a growing number of Maastricht University students feel welcome in Macau. I hope this new bridge will serve as an opportunity for students from East and West to appreciate IPR, international trade and cultural diversity.

I am heavily indebted to my parents and parents in law for their dedication that has always been enabling.

This lecture is dedicated to my beautiful children Elin and Natan, and to my wife Renée. Nothing I can ever say describes the unwavering love, support and joy that I experience from having you in my life.

Ladies and Gentlemen, I have tried to share with you my fascination with intellectual property law and its increasing role in a globalising world. Intellectual property law is one of the most dynamic areas of law. Domestic, regional and global developments take place at a pace that is often dazzling. I remain therefore a student, forever trying to build bridges from the known to the unknown. As I continue to learn the art of the trade from my colleagues my aim is to contribute some building blocks for bridges to be built by others. For now, though, my aspirations are not so high. You have been exhausted and deserve refreshments.

Ik heb gezegd. 
